\title{
The Role of Positive Emotion as a Mediator between Psychological Capital and Work Engagement
}

\author{
Nerinda Rizky Firdaus \\ Faculty of Psychology at Airlangga University \\ nerinda.rizky.firdaus-2018@psikologi.unair.ac.id
}

\begin{abstract}
This research aimed to examine the role of positive emotions as a mediator between psychological capital and work engagement. This research conducted on 129 employees in Surabaya using a convenience sampling technique. This study used a quantitative approach through surveys using UWES (Utrecht Work Engagement Scale), RCQ (Psychological Capital Questionnaire), and PANAS (Positive Affect and Negative Affect Schedule). Data were analyzed using path analysis to test the relationship between the variables. The results showed that positive emotion doesn't have a role as a mediator between psychological capital and work engagement. These findings indicated that employees with hope, self-efficacy, resilience, and optimism could generate vigor, dedication, and absorption in their work without experiencing positive emotion. The implication of this research concluded that the company needs to cultivate hope, resilience, self-efficacy, and optimism to employees so that employees have the vigor, dedication, and absorption in their work.
\end{abstract}

Keywords: positive emotion, psychological capital, work engagement.

Received I4 March 2019/Accepted 25 May 2019 @JEHCP All rights reserved

\section{Introduction}

Engagement in employees is seen as positive and desirable for the organization (Albrecht, 2010). Engaged employees will use their abilities to the fullest while working. This will improve the quality of employee responsibilities and performance at work. Employees will also dare to take various initiatives, such as developing new ideas and taking various opportunities. Employees will also be willing to help organizations community such as mentoring, volunteering, or paying attention to coworkers. The current study examines the role of positive emotions as a mediator between psychological capital and work engagement. 
Employees who dare to take the initiative will be able to improve their work and try to become leaders in their scope of work. Employees will do more than what is stated in the job description; employees will make their work more dynamic (Leiter \& Bakker, 2010). According to a survey by Gallup (2017a), employees who have work engagement show fewer turnover (24\% to $59 \%)$, shrinkage $(28 \%)$, workplace accidents $(70 \%)$ and absence $(41 \%)$ and show increase in customer ratings (10\%), profitability $(21 \%)$ and productivity (I7\%) compared to employees who do not have work engagement. Psychometrics Canada (20II) examined professionals who worked in human resources filed, resulting in as many as $82 \%$ said that it was very important to overcome employee engagement. Various benefits are obtained from engaged employees, such as extra-role behavior $(38,8 \%)$, increase in productivity $(26,6 \%)$, working relations $(12,7 \%)$, customer satisfaction $(9,5 \%)$, loyalty $(7,6 \%)$, communication $(2,1 \%)$ and show fewer turnover ( $1,3 \%)$ and absences $(1 \%)$.

Albrecht (2010) states that when employees are not engaged, employees just present only physically at work. These employees do not devote emotions, energy, and passion for work. Disengaged employees have little or no emotional involvement in their roles in work, do not care about organizational goals, and rarely enjoy work. Psychometrics Canada (20II) shows that the majority of HR professionals (69\%) indicate that work engagement is a problem in the organization. Disengaged employees influence the results of the organization. These disengaged employees affected organization in unfavorable things, such as dysfunctional work relations (29\%), low productivity (25\%), no extra-role behavior (17,3\%), 7,8\% increased in turnover, 6,7\% increased in absence, $6,2 \%$ increased in customer dissatisfaction, $4 \%$ increased in poor communication and 3,5\% increased in infidelity. The survey by Gallup (20I7b) in 2015 to 1429 employees in Germany showed that employees who are actively disengaged eliminate productivity by 75,6 to 99,2 million Euros per year. Other economic losses caused by disengaged workers cost as much as 187,9 million Euros to 287,1 million Euros per year. This data shows that engagement is an important topic, and organizations need to maintain their engaged employees. 
Work engagement defined as a positive, fulfilling, work-related state of mind that is characterized by vigor, dedication, and absorption (Schaufeli, Salanova, Gonzalez-Roma, \& Bakker, 2002). According to Taris, Schaufeli, and Shimazu (2010), employees who have work engagement will work hard (vigor), involve (dedication), and feel happy (absorption) with their work. Schaufeli and Bakker (2004a) state that vigor is characterized by high levels of energy and mental endurance while working, the willingness to try in work, perseverance, also when it faces difficulties. Dedication means when employees become very involved in their work, and feeling important, inspired, enthusiastic, proud, and view work as a challenge. Absorption characterized by concentrating fully on employees work and working happily, employees feel the time passes quickly at work and the difficulty to separate themselves from their work.

Job demand and work control are one of the predictors of work engagement. The theory that explains this predictor is the demands-control model (DCM) by Karasek (1979). According to this balanced model, mental tension or work stress is caused by a high level of job demands, such as overloaded work and low level of job control, or inequality between job control and job demands. The DCM theory is very simple because it only focuses on one aspect of job demands, namely, workload and one aspect of work resources, namely work control. This theory states that the balance between the demands of work and job control will result in low work stress.

The other predictors of work engagement are personal resources and job resources. These predictors are explained by the Job Demand-Resources Model or JD-R Model by Bakker and Demerouti (2008), which are the most widely quoted theories and are used in explaining work engagement. This theory shows that work resources, such as autonomy, feedback, support and personal resources, such as self-efficacy, resilience, and optimism predict work engagement and will have an impact on organizational outcomes, such as performance (extra-role and in-role behavior), financial and creativity results (Albrecht, 2010). 
Based on the views of some of these researchers, there are gaps in the JD-R Model and DCM Theory, namely DCM Theory states that predictors of work engagement are job demands and work controls, while the JD-R Model states the predictors of work engagement are personal resources and work resources. The existence of these differences and gaps becomes an opportunity for the researcher to conduct a study using the JD-R Model as a theoretical framework that examines work engagement.

Based on the preliminary study, the researcher interviewed several employees at one company in Surabaya, and some employees showed indications of low engagement. Employees feel less energized at work when facing consumers who don't want to pay for their products. This shows the lack of vigor in employees. Some employees also do not work optimally and are not fully involved in work, so they do not get a profit for themselves and the company. This interview illustrates the lack of dedication in employees. Employees also show a lack of persistence, such as a lack of focus on work because they think of other things, and this illustrates the lack of absorption of employees. This initial study indicates that there is a need to develop an employee's engagement at the company. This study aims to find out a comprehensive mapping of the factors that can develop an employee's engagement.

Psychological capital defined as positive psychological state of an individual characterized by having self-efficacy to be used to accomplished challenging task, creating positive attribution (optimism) about success in present and in afterward, determined towards the goal and if necessary directing the way to the goal (hope) to succeed and when faced with problems and difficulties, individuals can survive and rise again, even exceed the initial effort (resilience) to achieve success (Luthans, Youssef, \& Avolio, 2007). Psychological capital also influences employee's engagement because the dimensions of psychological capital are directly related to the dimensions of work engagement (Sweetman \& Luthans, 2010). Psychological capital has four dimensions, which are optimism, self-efficacy, resilience, and hope. Efficacy can be understood as a belief in achieving success or having the confidence to succeed and will motivate someone to do a new action. In the everyday sense, optimistic individuals are individuals who expect 
something positive and desirable to happen in the future, on the contrary, pessimistic individuals have negative thoughts and are sure bad things will happen in the future. Hope in individuals means having willpower and pathways to achieve their goal. Resilience reflects an ability to 'bounce back' from failures, conflicts, difficulties, and even positive events such as increasing progress and responsibility (Suryanto, 2010).

Psychological capital is a personal resource that, according to JD-R models, plays a role as predictors of work engagement (Bakker \& Demerouti, 2008). Psychological capital and work engagement have not only a direct relationship. The study by Avey, Wersning, and Luthans (2008) proves that positive emotions act as mediators between psychological capital and work engagement. A high level of psychological capital can trigger positive emotions to emerges and increases, and this will make employees have work engagement (Sweetman \& Luthans, 2010). This is supported theoretically through the theory of cognitive-emotional mediation in the workplace (Lazarus, 1993). This theory suggests that beliefs, expectations, psychological judgments, or efficacy, optimism, and resilience, namely overall psychological capital is a source of positive emotions and also an employee's behavior and attitude, namely work engagement (Sweetman \& Luthans, 20I0).

Psychological capital increases positive emotions through the way employees interpret an event. For example, employees view events in a positive way when they have self-efficacy, optimism, resilience, and hope. Tugade and Fredrickson (2004) justify that resilience as cognitive states and abilities can be antecedents of positive emotions because individuals with high resilience are more likely to experience positive emotions even amid stress. Individuals with such psychological capacities are tending to experience positive emotions; even some coworkers consider the situation as stressful. Employees with low psychological capital will experience a low level of positive emotion and are tend to experience deviant behavior and cynical attitudes, maladaptive and reduce positive organizational change (Avey, Wersning \& Luthans, 2008). 
Broaden-and-build theory by Fredrickson (1998) explained that positive emotions could broaden plans for individual actions and thoughts and build enduring personal resources physically and socially. This means a momentary emotional state can produce conditions that trigger work engagement through the development of plans and actions. According to broaden aspects, positive emotions develop plans, and negative emotions constrict action plans. Positive emotions act as a remedy to the negative emotion's effects, improve, and restore the effects caused by negative emotions. Positive emotions having a role called the undoing hypothesis (Fredrickson, 200I). According to the undoing hypothesis, employees with positive emotions have lower cynicism towards organizational change, and as a result, employees with positive emotions can trigger positive organizational outcomes, such as work engagement (Avey, Wersning \& Luthans, 2008).

Fredricskon (200I) states that generated positive emotions also contribute to building extensive enduring resources, ranging from intellectual, physical, psychological, and social resources. Positive emotions are characterized by attention, alert, interested, enthusiastic, excited, proud, inspired, strong, determined, and active (Watson, Clark \& Tellegen, 1998). According to Fredrickson (2013), excitement creates an urge to play and be involved, or readiness to engage and be attached to something present and build personal resources in the form of increasing skills to learn through involvement in the experience. Interest builds an urge to explore, learn, immerse themselves in new things and thus be able to develop themselves and build knowledge, which is a long-lasting personal resource for employees. Pride creates an urge to crave even greater achievements in a similar field. The resources built are achievement motivation. Inspiration creates a drive to improve oneself, achieve something higher or the best. The resources built are motivations for personal development. All of the enduring resource above functions as a backup to be used when individuals face a threat.

Positive emotions can also create self-reinforcement increasing work engagement. According to Salanova, Schaufeli, Xanthopulou, and Bakker (2010), work engagement as a direct result of positive emotions shows that work engagement is the result of expanded cognitive function and 
resource development. Employees who often experience positive emotions in the workplace show affective state, positive and more persistent condition, namely work engagement. In this context, employees who often feel enthusiasm, pride or excitement at work are more likely to be interested in things that must be done, and as a result, employees are in a more motivated state of energy, dedication, and immersion in their work.

The relationship between these variables shows that when employees have psychological capital, the employee will have work engagement. This is by the JD-R model; personal resources are factors that influence work engagement (Bakker \& Demerouti, 2008). However, this does not happen immediately; employees who have psychological capital will have positive emotions. This is following the theory of cognitive mediation of emotions in the workplace (Lazarus, 1993) which suggests that psychological capital is an antecedent of positive emotions because psychological capital possessed by employees will produce a positive interpretation. When employees have positive emotions, employees will look at and respond to a situation with a more open and broad mind in thinking about actions to be taken to deal with a situation; employees will also have resources that can help them in facing certain situations. Positive emotions that employees have will also prevent negative behaviors in the organization. This is under the broaden-and-build theory by Fredrickson (1998) saying that positive emotions will develop broad the plan of action and thoughts of individuals, build lasting personal enduring resources, and have undoing effects. This can help individuals to have work engagement (Salanova, Schaufeli, Xanthopulou \& Bakker, 2010; Avey, Wersning \& Luthans, 2008; Lazarus, 1993; Sweetman \& Luthans, 2010).

The novelty of this study is a lot of previous researches do not use positive emotions as a mediator, they only examine the relation between personal resources or psychological capital with work engagement or test the relation between positive emotions with work engagement (Eman \& Ishal, 2016; Ouweneel, Blanc \& Schaufeli, 20II; Sweetman \& Luthans, 20I0; Bakker \& Demerouti, 2008; Xanthopoulou, Bakker, Demerouti \& Schaufeli, 2007). Although the research by Ouweneel, Blanc, and Schaufeli (20II) tested the causal cycle of positive emotions, personal 
resources, namely psychological capital and study engagement, their research uses the conservation of resources (COR) theory, meanwhile, this study using JD-R Model as a theoretical frame. Based on preliminary study data and previous studies, the researcher wants to test this problem further by conducting a study about the role of positive emotions as a mediator between psychological capital and work engagement using the JD-R Model as a theoretical frame.

Hypotheses

Positive emotions act as mediators between psychological capital and work engagement.

\section{Method}

Participants

Participants that involved in this study were from one company from various divisions, such as marketing, billing, administration, and other staff from Lumajang and Surabaya branches which carried 193 employees. Sampling process is done using Raosoft software with a confidence level of $95 \%$ and the result is a sample of 129 employees, which consists of 51 males and 78 females from various position, such as salesman ( 85 employees), coordinator ( 15 employees), collectors (14 employees), and other staff (15 employees) and various division, such as marketing (100 employees), billing ( 16 employees), administration (6 employees) and others ( 7 employees). The research sampling technique used was convenience sampling, which is a sample selection technique, based on consideration, namely whoever considered fits according to the profile are chosen as a source of data by the researcher and can be used as a sample (Sugiyono, 2006). The respondent's criteria are male and female workers at all ages in all divisions who have worked at least one year at the company. Data were collected by survey using questionnaires.

\section{Measurements}

Work engagement is measured using a scale compiled by researcher referring to UWES (Utrecht Work Involvement Scale), introduced by Schaufeli and Bakker (2004b) and consisting of 17 items, each item represents aspects of work engagement, which are vigor, dedication, and 
appreciation (e.g.: (3.)Ketika saya bekerja, waktu berlalu dengan cepat (4.)Saya antusias dengan pekerjaan saat ini. (10.)Saya bangga dengan pekerjaan yang saya jalani.) This scale has a good level of validity, using CVR (content validity ratio) with the score 0.555 and also showed a good level of reliability with a Cronbach's Alpha $=0.734$. CVR (content validity ratio) is used to test the validity of this scale with the score $>0.5$. This scale uses a five-point Likert scale as an answer ( $\mathrm{I}=$ never happened, 5 = always occurs). The higher score reflects a higher level of work engagement in employees and vice versa.

Psychological capital is measured using a scale compiled by researcher referring to PCQ (Psychological Capital Questionnaire) which introduced by Luthans, Youssef, and Avolio (2007) and consisting of 21 favorable items and 3 unfavorable items, amounting to a total of 24 items, each item represents aspects of psychological capital, which are optimism, resilience, hope, and self-efficacy (e.g: (6.) Saat ini saya memiliki harapan yang kuat dalam mengejar target pekerjaan. (7.) Saya mengatasi masalah pekerjaan dengan satu atau berbagai macam cara (8.) Saya akan mengalami kegagalan, jika ada kemungkinan saya gagal dalam pekerjaan). This scale has a good level of validity, using CVR (content validity ratio) with the score 0.675 and also showed a good level of reliability with a Cronbach's Alpha $=0.84 \mathrm{I}$. This scale uses a five-point Likert scale as an answer ( $I=$ never happened, five = always occurs). The higher the score reflects a higher level of psychological capital in employees and vice versa.

Positive emotions are measured using a scale compiled by researcher referring to PANAS (Positive Affect and Negative Affect Schedule) which introduced by Watson, Clark, and Tellegen (1988) and consisting of 20 items. (e.g: (2.) Saya tertekan saat mengerjakan tugas-tugas saya. (3.) Saya bergairah saat mengerjakan tugas-tugas saya (4.) Saya kecewa jika atasan saya tidak mendengarkan aspirasi saya.). This scale has a good level of validity, using CVR (content validity ratio) with the score 0.567 and also showed a good level of reliability with a Cronbach's Alpha $=0.719$. This scale uses a five-point Likert scale as an answer $(\mathrm{I}=$ never happened, five $=$ always occurs). According to the score, the high score represents a high level of positive emotions in employees and vice versa. 


\section{Data analysis}

The data were analyzed using statistical analysis through SPSS v.20. Statistical analysis includes validity and reliability tests for item scales; assumptions test namely normality test and linearity test, then the hypothesis test. The relationship between independent variables, dependent variables, and mediator variables will be analyzed using path analysis with regression as statistical analysis. The hypothesis will be accepted if it meets the significance requirements $<0.05$.

\section{Procedure}

The preparations made by the researcher before conducting research include conducted a preliminary study by interviewing some employees to discover their level of work engagement, psychological capital, and positive emotion. The researcher then compiled the work engagement, psychological capital and positive emotion scale referring to the original version and made a complete survey consisting of six parts, namely informed consent, profile, work engagement scale, psychological capital scale, positive emotional scale, and open questionnaire. First, the researcher gave 50 questionnaires to be distributed to employees in the CKA Surabaya office. Two days later, the researcher gave 142 questionnaires to the employees in the Lumajang branch office. In a week, researchers took 7I questionnaires that had been filled from the Lumajang branch office, and the researchers took 26 questionnaires that had been filled in from the Lumajang branch office and a week later researcher took 32 questionnaires which had been filled from Surabaya branch office. After the data retrieval process is done, the next process is the calculation of data and processing data using the SPSS v.20. At this stage, the researcher coding the data of all subject answers in Microsoft Excel, then categorizing them according to the variables, dimensions, and demographics of the subject. The data was then entered into the SPSS program and carried out reliability testing, validity test, assumption test, hypothesis test, norm making, and also cross-tabulation of all variables with subject demographic data. 


\section{Result}

Testing the hypothesis in this study uses path analysis with regression as statistical analysis. This test is used to determine the influence of positive emotions as a mediator between psychological capital and work engagement. Path analysis test results showed in table I.

Table I

Hypothesis test result

\begin{tabular}{|c|c|c|c|c|c|c|}
\hline Variable & $\mathrm{R}^{2}$ & $\begin{array}{c}\text { Standardized } \\
\text { Beta }\end{array}$ & $\begin{array}{c}\text { Unstandardized } \\
\text { Beta }\end{array}$ & $\begin{array}{l}\text { SD } \\
\text { Error }\end{array}$ & $\mathrm{t}$ & $P$ \\
\hline $\begin{array}{l}\text { Psychological Capital with } \\
\text { Positive Emotion }\end{array}$ & 0,616 & $\beta 2=0,787$ & & $S \beta 2=$ & 14,363 & 0,000 \\
\hline $\begin{array}{l}\text { Psychological Capital with } \\
\text { Work Engagement }\end{array}$ & 0,308 & $\beta I=0,558$ & & $\begin{array}{l}S \beta I= \\
0,088\end{array}$ & 4,688 & 0,000 \\
\hline $\begin{array}{c}\text { Positive Emotions with Work } \\
\text { Engagement }\end{array}$ & 0,308 & $\beta 3=0,008$ & & $\begin{array}{l}S \beta 3= \\
0,167\end{array}$ & 0,063 & 0,950 \\
\hline
\end{tabular}

Based on the results of the hypothesis test, the unstandardized beta value of psychological capital relationships with positive emotions is 0,417 with a value of $p=0,000(p<0,05)$, this means there is a relationship between psychological capital and positive emotions. Psychological capital also has a relationship with work engagement, with unstandardized beta values of $0,4 \mid 4$ and $p=0,000(p<0,05)$. Also, the regression result shows that positive emotions do not have a relationship with work engagement, with unstandardized beta values of $0,01 \mathrm{I}$ and a significance value of $0,950(p>0,05)$ (see table 1$)$.

Following is the chart of the results of path analysis:

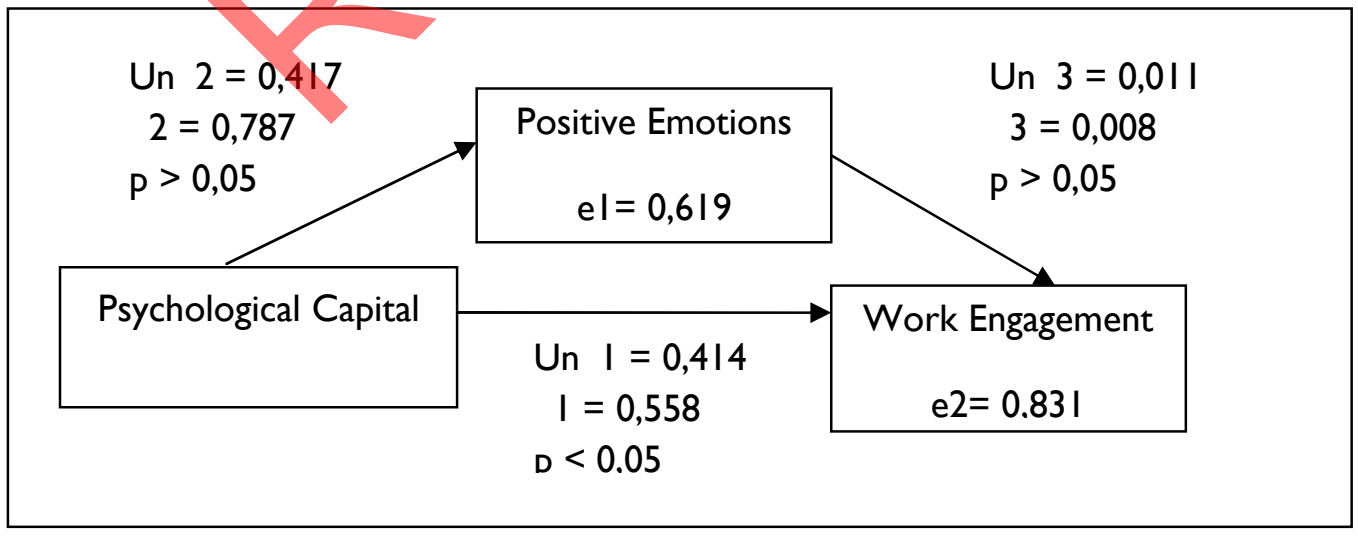

Figure I. Coefficient Path 
The power of the effect of positive emotions as a mediator between psychological capital and work engagement calculated using the $t$ count formula:

$t=(B 2 \times \beta 3) / S B 2 \beta 3=0,028$

Based on the above calculations, the value of $t$ count $=0.028$, which is smaller than $t$ table $(I, 96)$ with a significance level of 0.05 . This means that there is no influence of mediation. The result of this study rejects the research hypothesis, which means positive emotions do not act as mediators between employee's psychological capital and work engagement.

Based on the results of the hypothesis test above, the researcher conducted an additional test to explain the relationship between variables, namely multiple regression using the stepwise method and regression test between variables.

Table 2

Multiple regression with the stepwise method test result

\begin{tabular}{cccccccc}
\hline Variable & $\mathrm{R}^{2}$ & $\begin{array}{c}\text { Standardized } \\
\text { Beta }\end{array}$ & $\begin{array}{c}\text { Unstandardized } \\
\text { Beta }\end{array}$ & $\begin{array}{c}\text { SD } \\
\text { Error }\end{array}$ & $\mathrm{F}$ & $\mathrm{t}$ & $\mathrm{P}$ \\
\hline $\begin{array}{c}\text { Psychological Capital } \\
\text { with Work Engagement }\end{array}$ & 0,616 & $\beta=0,564$ & $\mathrm{Un} \beta=0,418$ & $\begin{array}{c}\mathrm{S} \beta= \\
0,054\end{array}$ & 59,362 & 7,705 & 0,000 \\
\hline
\end{tabular}

The results of multiple regression tests using the Stepwise method show an F value of 59,336 with $p<0,05$. This shows that positive emotions can act as predictors of work engagement. The stepwise model also shows a relation between psychological capital and work engagement is a stronger model than the relation between positive emotions and work engagement because the model listed in the table is the relationship between psychological capital and work engagement and positive emotions are listed in the excluded variable (See table 2). 
Table 3

Regression test result

\begin{tabular}{ccccc}
\hline Variabel & $\mathrm{F}$ & $\mathrm{R}^{2}$ & $\mathrm{r}$ & $\mathrm{P}$ \\
\hline $\begin{array}{c}\text { Positive Emotion } \\
\text { with Work } \\
\text { Engagement }\end{array}$ & 31,693 & 0,200 & 0,447 & 0,000 \\
\hline $\begin{array}{c}\text { Psychological } \\
\text { Capital with } \\
\text { Work }\end{array}$ & 59,362 & 0,319 & 0,564 & 0,000 \\
Engagement & & & & \\
\hline
\end{tabular}

The results of the positive emotion regression test with work engagement showed an $F$ value of 31,693 and $p<0,05$. This shows a relation between positive emotions and work engagement with a correlation $r$-value of 0,447 . The $R^{2}$ value of 0,200 indicates a contribution of positive emotions to work engagement of $20 \%$ (See table 3 ).

The regression test of psychological capital with work engagement shows an F value of 59,336 and $p<0,05$. This shows a relation between psychological capital and work engagement with a correlation $r$-value of 0,564 . The $R^{2}$ value of 0,319 shows the contribution of psychological capital to work engagement by $31.9 \%$ (See table 3 ).

\section{Discussion}

The results of this study are positive emotions that do not act as mediators between psychological capital and work engagement. This finding shows that employees who have optimism, hope, resilience, and self-efficacy do not need to be followed by positive emotions to generate vigor, dedication, and absorption in their work. The results of this hypothesis do not support the study of Sweetman and Luthans (2010) and Avey, Wersning, and Luthans (2008) research which states that when employees have a high level of psychological capital, employees will tend to have high positive emotions and will cause employees to have work engagement.

Positive emotions do not act as mediators can occur because of two reasons. First, positive emotions can stand alone as predictors of work engagement without psychological capital. According to Salanova, Schaufeli, Xanthopulou, and Bakker (2010), as a direct result of positive 
emotions, work engagement emerges because of broadening cognitive function and resource development. Employees with positive emotions in the workplace will experience positive mental state and more persistent conditions, namely, work engagement. Employees who often feel enthusiasm, pride or excitement at work are more likely to be interested in doing their responsibility, and as a result, employees are in a more motivated state of energy, dedication, and immersion in their work.

The relation between positive emotions and work engagement can be analyzed using Fredrickson (1998) broaden and build theory. Fredrickson (1998) states that positive emotions will broad plans for individual actions and thoughts and build enduring personal resources. This can result in conditions that trigger work engagement through expanding plans and actions, resulting in positive organizational outcomes, such as work engagement (Avey, Wersning \& Luthans, 2008). Fredrickson (200I) said that the aspects of positive emotions also contribute to building enduring resources, ranging from intellectual, physical, social, and psychological resources. This phenomenon occurs in employees of UD. CKA, because they are experiencing pride and strong determination when trying to achieve work performance. Fredrickson (20l3) explains that pride creates an urge to crave greater achievements in similar fields. The resources built are achievement motivation.

The second reason for positive emotions does not act as mediators between psychological capital and work engagement to employees at UD. CKA is that psychological capital is strong enough to generate work engagement without going through positive emotions. The direct relation between psychological capital and work engagement is a stronger model than the relation between positive emotions and work engagement because positive emotions become excluded variables, namely variables that are not included in the main model (Field, 2009). The contribution of psychological capital is also greater than the contribution of positive emotions to work engagement. The direct relation between psychological capital and work engagement supports the JD-R model (Bakker and Demerouti, 2008) that explains employees who have personal resources or psychological capital and active coping styles; employees will have work 
engagement that will help them control and influence the work environment successfully and achieve career success.

Psychological capital influences employee engagement because the dimensions of psychological capital are directly related to the dimensions of work engagement (Sweetman \& Luthans, 20I0). Xanthopoulou, Bakker, Demerouti, and Schaufeli (2007) show that employees who have work engagement are the ones with high self-efficacy, believing in the ability to meet work demands. Confident employees can apply hope, optimism, and resilience to their tasks and in certain fields of their lives (Luthans, Avolio \& Youssef, 2007). Employee self-efficacy relates to the vigor aspect because individuals will have energy and resilience to fulfill various tasks and when employees can accomplish a particular task, they become absorbed in the overall achievement of the task (Sweetman \& Luthans, 2010). Optimism can make employees more ready to accept tasks, given there are hopes for positive results. This ready and available psychological state triggers work engagement through appreciation (Kahn, 1990). Hope related to vigor in work engagement. Hope can increase energy to achieve goals. Also, in difficult situations, with hope, employees will show their dedication continuously to achieve goals (Sweetman \& Luthans, 2010). In work engagement, especially in vigor, resilience is equated with persistence (Sweetman \& Luthans, 2010). The relation between psychological capital and work engagement shows that employees have confidence in their ability to complete each task or problem, have hope, optimism, and the ability to get back up after a failure which makes them have energy, involved and immersed in their work.

Participant's positions dominated by employees who work in the marketing division may become the other causes of positive emotions do not have a role as a mediator between psychological capital and work engagement. Their position as a salesman, collector, and coordinator requires employees to deal with consumers every day and many events causing employees to suppress their positive emotions, especially when dealing with consumers. Their job demands them to have more confidence, hope, optimism, and resilience in dealing with their duties, such as in finding consumers, accepting rejection from consumers, collecting 
payments, and fulfilling sales targets. Employees who have confidence and optimism that they will get consumers will eager to market their products. Employees who feel all problems have a solution will try to face consumers by using various ways and will continue to concentrate and be involved in solving the problem caused by their consumers. This finding explained that confidence, hope, optimism, and resiliency are more needed in their work rather than positive emotions, but it does not mean that positive emotion does not have any impact, it means that the impact is smaller compared to psychological capital.

This study was limited by three variables, namely, work engagement, psychological capital, and positive emotions. Many factors influence work engagement, but this study uses psychological capital as a predictor and positive emotions as mediators. Moreover, the sample in this study is located only in East Java. This research only uses a quantitative method by surveying through questionnaires.

\section{Conclusion}

Based on the discussion presented, the conclusion of this study is positive emotions do not act as a mediator between psychological capital and work engagement. We can say that the relationship between psychological capital and work engagement is direct and does not use positive emotions as a mediator. The results of this hypothesis can be explained with two reasons. First, positive emotion act as the predictor of work engagement. Second, psychological capital is strong enough to generate work engagement in employees. So, employees who have hope, self-efficacy, resilience, and optimism can generate work engagement without having positive emotions in between or do not need to be followed by positive emotions to generate vigor, dedication, and absorption in their work. The roles of positive emotions do not function as a mediator between psychological capital, and work engagement can be caused by the work position and division of participants.

Future research can further examine the role of positive emotions with work engagement, especially in companies and organizations in Indonesia, moreover using various research 
methods and variables. This is intended to enrich the discussion about the role and the function of positive emotions in work engagement in Indonesia. Future studies can test the role of positive emotions based on their aspects. This is intended to explain the contribution of positive emotions in influencing certain variables. Further research can test the causal relationship between work engagement, positive emotions, and psychological capital. Researchers are expected to assist employees when working on questionnaires to minimize errors to occur. Another recommendation for the company is they can increase employee engagement by increasing psychological capital or building a work environment that supports employees to have hope, optimism, resilience, self-efficacy so that employees have enthusiasm, dedication, and absorption to their work. The company can carry out training to increase psychological capital referring to $\mathrm{PCl}$ (Psychological Capital Interventions) by Luthans, Avey, Avolio, Norman and Combs (2006), namely increasing self-efficacy by challenging employees and setting clear, measurable and achievable goals. Increase optimism by showing the success of employees and the success of coworkers. Increase expectations by developing employee willingness and helping employees plan ways to achieve goals. Increase resilience by providing resources, relationships, and emotional support to employees to help them recover from stress, conflict, failure, or changes in responsibility. Future research can also test this training to see the effect of Psychological Capital Interventions training on employee's work engagement.

\section{Acknowledgment}

I thank Suryanto for providing references to help me in improving this research. I thank Frikson C. Sinambela and Widhawan Aryo Pradhita as they are my mentor through this study. I also thank the reviewer from Ahmad Dahlan University for the comments that greatly improved the earlier version of this manuscript. My gratitude is also shown to the CEO of the company for allowing me to conduct this research in their company. I also appreciate all of the employees who spend their time to participate in this research. I would also thank Ahmad Dahlan University and the University of Africa who allowed me to present this study at the International Conference on Community Psychology, Humanization and Religio-Cultures in 
Yogyakarta on February 6, 2019, and Airlangga University who supported this study to become a journal article.

\section{References}

Albrecht, S. (2010). Handbook of Employee Engagement Perspectives, Issues, Research, and Practice. Cheltenham: Edward Elgar.

Avey, J., Wernsing, T., \& Luthans, F. (2008). Can Positive Employees Help Positive Organizational Change? Impact of Psychological Capital and Emótions on Relevant Attitudes and Behaviors. The Journal Of Applied Behavioral Science, 44(I), 48-70. http://dx.doi.org//0.1 I77/002/8863073/ I470

Bakker, A. \& Demerouti, E. (2008). Towards a model of Work Engagement. Career Development International, 13(3), 209-223. http://dx.doi.org// 0.1 I08/13620430810870476

Field, A. P. (2009). Discovering statistics using SPSS ( $3^{\text {rd }}$ edition). London: Sage

Fredrickson, B. L. (20/3). Positive Emotions Broaden, and Build. In Devine, P \& Plant, A. Advances in Experimental Social Psychology (Vol. 47) Burlington: Academic Press.

Fredrickson, B. (1998). What good are positive emotions?. Review Of General Psychology, 2(3), 300-319. http://dx.doi.org//0.1037// 1089-2680.2.3.300

Fredrickson, B. (200I). The role of positive emotions in positive psychology: The broaden-andbuild theory of positive emotions. American Psychologist, 56(3), 218-226. http://dx.doi.org//0.1037/0003-066x.56.3.218

Gallup, I. (2017a). The Worldwide Employee Engagement Crisis. Gallup.com. Retrieved 30 March 2017, from http://www.gallup.com/businessjournal//88033/worldwide-employeeengagement-crisis.aspx

Gallup, I. (2017b). The Negative Impact of Disengaged Employees on Germany. Gallup.com. Retrieved 30 March 2017, from http://www.gallup.com/businessjournal/I90445/negativeimpact-disengaged-employees-

germany.aspx?g_source=disengaged\&g_medium=search\&g_campaign=tiles

Kahn, W. (1990). Psychological Conditions Of Personal Engagement And Disengagement At Work. Academy Of Management Journal, 33(4), 692-724. http://dx.doi.org/I 0.2307/256287

Karasek, R.A. (1979), "Job demands, job decision latitude, and mental strain: implications for job redesign," Administrative Science Quarterly, 24, 285-308. 


\section{Journal of Educational, Health and Community Psychology Nerinda \\ Vol 8, No 2, 2019 E-ISSN 2460-8467 Rizky}

Firdaus

Katz. (20II). Multivariable Analysis: A Practical Guide for Clinicians and Public Health Researchers (Cambridge medicine) (Ist ed.). Cambridge University Press.

Lazarus, R. (1993). From Psychological Stress to the Emotions: A History of Changing Outlooks. Annual Review Of Psychology, 44(I), I-2I. http://dx.doi.org/I0.I I46/annurev.psych.44.I.I

Leiter, M. \& Bakker, A. (20I0). Work engagement (Ist ed.). New York: Psychology Press.

Luthans, F., Avey, J., Avolio, B., Norman, S., \& Combs, G. (2006). Psychological capital development: toward a micro-intervention. Journal Of Organizational Behavior, 27(3), 387393.http://dx.doi.org/10.1002/job.373

Luthans, F., Youssef, C. M., \& Avolio, B. J. (2007). Psychological capital: Developing the human competitive edge. Oxford: Oxford University Press.

Ouweneel, E., Le Blanc, P., \& Schaufeli, W. (20I I). Flourishing students: A longitudinal study of positive emotions, personal resources, and study engagement. The Journal Of Positive Psychology, 6(2), I42-I53. http://dx.doi.org//0.1080/I7439760.20 I I.558847

Psychometrics Canada. (20II). Control, Opportunity \& Leadership: A Study of Employee Engagement in the Canadian Workplace. Canada. Psychometrics Canada Ltd. https://www.psychometrics.com/wp-content/uploads/20I5/04/engagement_study.pdf

Salanova, M., Schaufeli, W. B., Xanthopoulou, D. \& Bakker, A. B. (2010). In Bakker, A., \& Leiter, M. Work engagement (Ist ed.). New York: Psychology Press.

Schaufeli, W \& Bakker, A. (2004b). Utrecht Work Engagement Scale. Preliminary Manual. Occupational Health Psychology Unit Utrecht University

Schaufeli, W., \& Bakker, A. (2004a). Job demands, job resources, and their relationship with burnout and engagement: a multi-sample study. Journal Of Organizational Behavior, 25(3), 293-3 I5. http://dx.doi.org// 0.1002/job.248

Schaufeli, W., Salanova, M., Gonzalez-Roma, V., \& Bakker, A. (2002). The Measurement Of Engagement And Burnout: A Two-Sample Confirmatory Factor Analytic Approach. Journal Of Happiness Studies, 3, 7I-92. Retrieved from http://www.wilmarschaufeli.nl/publications/Schaufeli/I 78.pdf

Suryanto. (2010). Modal Psikososial Dalam Membangun Kemandirian Bangsa. Speech, Airlangga University. 
Sweetman, D. \& Luthans, F. (2010). The power of positive psychology: Psychological capital and work engagement. In Bakker, A., \& Leiter, M. Work engagement (Ist ed.). New York: Psychology Press.

Taris, T. W., Schaufeli W. B. \& Shimazu, A. (2010). The push and pull of work: The differences between workaholism and work engagement. In Bakker, A., \& Leiter, M. Work engagement (Ist ed.). New York: Psychology Press.

Tugade, M., \& Fredrickson, B. (2004). Resilient Individuals Use Positive Emotions to Bounce Back From Negative Emotional Experiences. Journal Of Personality And Social Psychology, 86(2), 320-333. http://dx.doi.org//0.1037/0022-35|4.86.2.320

Watson, D., Clark, L., \& Tellegen, A. (1988). Development and validation of brief measures of positive and negative affect: The PANAS scales. lournal of Personality and Social Psychology, 54(6), I063-1070. http://dx.doi.org/10.1037/0022-35 I4.54.6.1063

Xanthopoulou, D., Bakker, A., Demerouti, E., \& Schaufeli, W. (2007). The role of personal resources in the job demands-resources model. International Journal Of Stress Management,

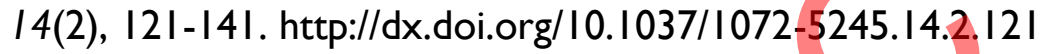

